\title{
Perceived E-Service Quality dan Brand Equity Produk Tcash
}

\author{
Putra Akbar Pangestu ${ }^{1}$, Indira Rachmawati ${ }^{2}$ \\ ${ }^{1,2}$ Manajemen Bisnis Telekomunikasi Informatika, Fakultas Ekonomi dan Bisnis, \\ Universitas Telkom \\ ${ }^{1}$ putraakbarpangestu@student.telkomuniversity.ac.id, \\ indirarachmawati@ telkomuniversity.ac.id
}

\begin{abstract}
ABSTRAK
Penelitian ini bertujuan untuk menguji dampak dari variabel Perceived E-Service Quality, Satisfaction, Trust, Terhadap Loyalty dan Brand Equity. Objek pada penelitian ini ditujukan kepada pengguna aktif Tcash di Kota Bandung. Sebanyak 400 responden sudah didapatkan melalui penyebaran kuesioner yang terdiri dari 35 butir pernyataan di Kota Bandung dengan mengunakan metode non probability sampling. Pengolahan data pada penelitian ini dilakukan dengan menggunakan SmartPLS 3.0. Hasil penelitian menyatakan bahwa variabel Delivery Quality memiliki pengaruh positif dan signifikan terhadap Trust, variabel Outcome Quality memiliki pengaruh positif dan signifikan terhadap Satisfaction, Trust dan Satisfaction memiliki pengaruh positif dan signifikan terhadap Loyalty, Loyalty memiliki pengaruh positif dan signifikan terhadap Brand Equty,Trust dan Satisfaction.
\end{abstract}

Kata kunci: Brand Equity, Loyalty, Perceived E-Service Quality, Satisfaction, Trust

\section{ABSTRACT}

This study aims to examine the impact of Perceived E-Service Quality, Satisfaction, Trust, Loyalty and Brand Equity variables. Objects in this study addressed to active users Tcash in Bandung. A total of 400 respondents have been obtained through the distribution of questionnaires consisting of 35 points statement in the city of Bandung by using the method of non-probability sampling. Data processing in this research is done by using SmartPLS 3.0. The result of this research stated that Delivery Quality variable has positive and significant influence to Trust, Outcome Quality variable has positive and significant influence to Satisfaction, Trust and Satisfaction has positive and significant influence to Loyalty, Loyalty has positive and significant influence to Brand Equty, Trust and Satisfaction.

Keywords: Brand Equity, Loyalty, Perceived E-Service Quality, Satisfaction, Trust

\section{PENDAHULUAN}

Perkembangan teknologi dan perubahan perilaku pembelian memacu manusia untuk terus berinovasi serta menciptakan layanan baru untuk memenuhi kebutuhan hidupnya. Salah satu inovasi tersebut adalah dari sistem transaksi yang semakin berkembang. Sistem transaksi baru diharapkan memenuhi kebutuhan manusia pada umumnya yang semakin memerlukan sistem transaksi yang aman, cepat, lebih mudah dan dapat dilakukan kapanpun dan dimanapun. Hal tersebut mendorong adanya layanan E-Money.

Jumlah transaksi dan nominal transaksi uang elektronik di Indonesia sejak tahun 2009 hingga 2016 selalu mengalami peningkatan (Bank Indonesia, 2017). Hal tersebut mendorong banyaknya penyedia layanan transaksi non tunai (E-Money) salah satunya adalah PT Telkomsel dengan produknya bernama Tcash. Tcash adalah layanan uang elektronik dari Telkomsel. Tcash berbeda dengan pulsa, dimana konsumen dapat menyimpan uang dan menggunakannya untuk semua transaksi. Telkomsel telah memiliki izin dari Bank Indonesia sebagai penyedia layanan uang elektronik. Tcash bisa digunakan oleh semua pelanggan Telkomsel, baik pascabayar ataupun prabayar ( $\underline{\text { https://digitalpayment.telkomsel.com) }}$ 
Jumlah pengguna Tcash di Jawa Barat terus mengalami peningkatan hingga 100\% (Arie \& Damhuri, 2017). Mayoritas pengguna Tcash tersebut adalah pengguna yang berdomisili di Kota Bandung (Arie \& Damhuri, 2017). Namun adanya peningkatan jumlah pengguna tersebut tidak berbanding lurus dengan jumlah pengguna aktif Tcash di Jawa Barat dan Kota Bandung.

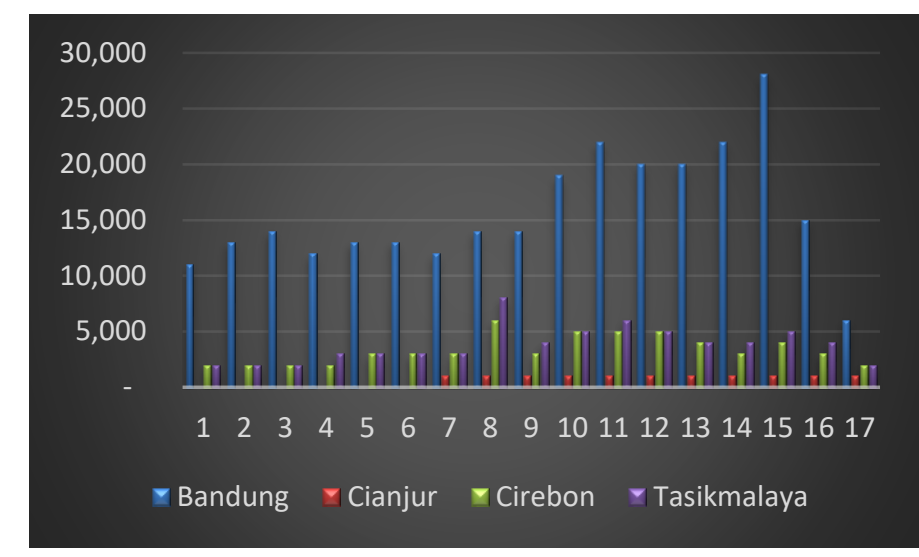

\section{Gambar 1. Jumlah Pengguna Aktif TCASH Jawa Barat \\ Sumber: www.republika.co.id}

\section{LANDASAN TEORI}

\section{Pemasaran}

Pemasaran adalah proses sosial dimana individu dan kelompok memperoleh apa yang mereka butuhkan dan inginkan melalui penciptaan, penawaran, dan pertukaran produk dan layanan bernilai dengan orang lain secara bebas.

\section{Perceived E-Service Quality}

Menurut (Kao \& Lin, 2016) Quality of E-Service terbagi menjadi dua dimensi yaitu Delivery Quality dan Outcome Quality.

\section{Delivery Quality}

Delivery Quality mengacu pada tahap interaksi pelanggan selama Penggunaan $e$-service dan empat sub-dimensi terkait untuk delivery quality dianggap dan disempurnakan. Delivery quality terbagi menjadi 4 sub-dimensi yaitu attractiveness of selection, information quality, ease of use, dan technical quality (Kao \& Lin, 2016). (1) Attractiveness of selection adalah pilihan layanan yang ditawarkan oleh penyedia layanan pelanggan mereka. (2) Information quality diadopsi untuk mengukur derajat layanan penyedia layanan mana yang bisa memberikan layanan komprehensif, tepat, dan informasi terbaru untuk penggunanya. (3) Ease of use mengacu pada sejauh mana pengguna layanan dapat memperoleh informasi yang mereka butuhkan atau menyelesaikan layanan tanpa banyak usaha. (4) Technical quality mengacu untuk mengevaluasi kestabilan layanan yang pelanggan rasakan selama proses interaksi. 


\section{Outcome Quality}

Outcome Quality adalah kualitas hasil dilihat sebagai apa yang ditinggalkan pelanggan setelah pengiriman layanan (Kao \& Lin, 2016). Outcome quality terbagi menjadi tiga subdimensi, yaitu: (1) Reliability : Sejauh mana layanan mobile banking bisa memberikan kinerja layanan yang konsisten dan stabil bagi penggunanya. (2) Functional benefit: Sejauh mana layanan mobile wallet mencapai tujuan sesuai dengan layanan yang dijanjikan. (3) Emotional benefit: Pengalaman layanan pengguna dan untuk mengukur sejauh mana layanan mobile wallet menginduksi emosi yang menyenangkan pelanggan.

\section{Trust}

Online trust adalah sebuah sikap kepercayaan diri dalam situasi online atau risiko bahwa kerentanan seseorang tidak akan dieksploitasi (Kao \& Lin, 2016).

\section{Loyalty}

Loyalty adalah komitmen yang sangat kuat untuk membeli ulang atau berlangganan kembali produk atau jasa yang lebih disukai secara konsisten di masa depan meskipun ada pengaruh situasional dan upaya pemasaran yang berpotensi menyebabkan keberalihan perilaku (Kotler \& Keller, 2016).

\section{Satisfaction}

Satisfaction adalah perasaan kesenangan atau kekecewaan seseorang yang diakibatkan oleh membandingkan sebuah produk atau kinerja layanan yang dirasakan (hasil) dengan harapan (Kotler \& Keller, 2016).

\section{Brand Equity}

Brand Equity dianggap sebagai satu rangkaian aset dan kewajiban merek yang terkait dengan merek, nama, dan simbolnya, yang menambah atau mengurangi nilai yang diberikan oleh produk atau layanan kepada perusahaan dan/atau kepada pelanggan perusahaan. (Kao \& Lin, 2016).

\section{Kerangka Pemikiran}

Pada penelitian ini penulis melakukan replikasi pada kerangka pemikiran yang dibuat oleh (Kao \& Lin, 2016). Kerangka pemikiran pada penelitian ini ditunjukkan pada Gambar 2. 


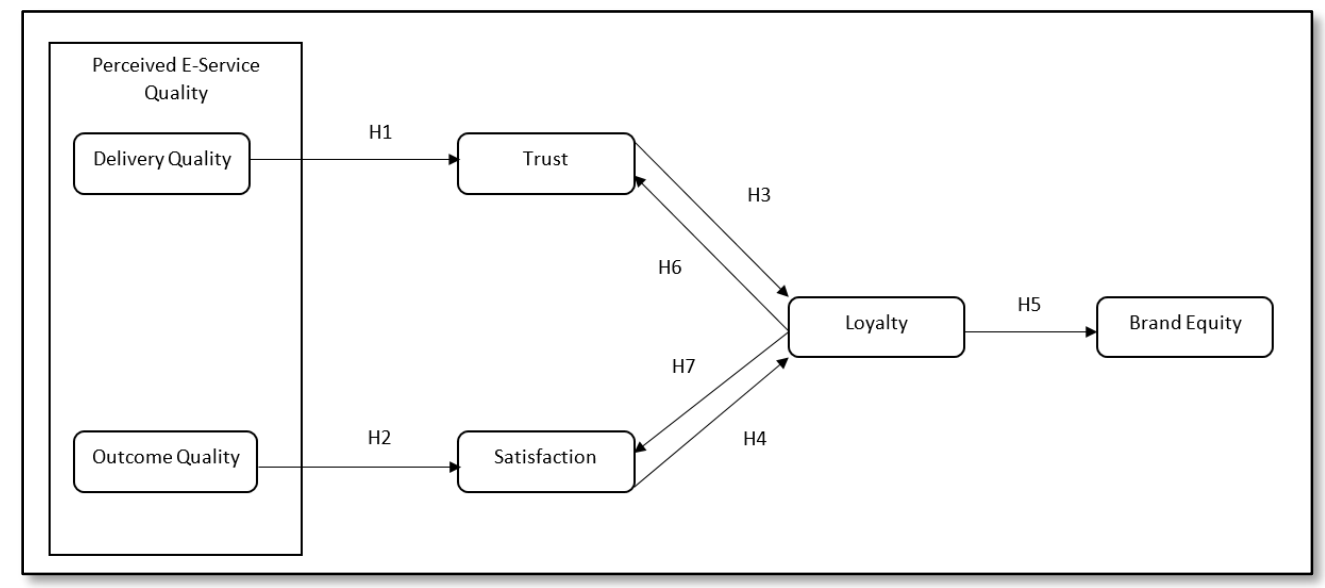

Gambar 2. Kerangka Pemikiran

Sumber: (Kao, Ta-Wei dan Lin, Winson T: 2016)

\section{METODE PENELITIAN}

Penelitian ini menggunakan metode penelitian kuantitatif karena pada penelitian ini penulis ingin mengetahui hasil dari suatu rencana dan pelaksanaannya. Tujuan utama dari penelitian ini adalah mengetahui hubungan antara variabel pembentuk hipotesis. Teknik pengambilan sampel dalam penelitian ini adalah non probability sampling dengan menggunakan convenience sampling dengan jumlah sebanyak 400 responden pengguna aktif layanan Tcash di Kota Bandung. Pengambilan sampel dilakukan dengan menyebarkan kuesioner secara online via Google Docs.

Teknik pengolahan data yang digunakan dalam penelitian ini adalah PLS-SEM, Partial Least Squares (PLS) adalah teknik statistika multivariat yang merupakan pembanding antara variabel dependen berganda, dan variabel independen berganda (Abdillah \& Jogiyanto, 2015).

\section{HASIL PENELITIAN DAN PEMBAHASAN}

\section{Hasil Penelitian}

\section{Karakteristik Responden}

Pada penelitian ini, karakteristik responden terbagi menjadi jenis kelamin, usia, pendidikan terakhir, pekerjaan, domisili, penghasilan, serta jumlah transaksi/bulan menggunakan Tcash. Berdasarkan hasil penyebaran kuesioner terhadap 400 responden, mayoritas responden berjenis kelamin laki-laki sebanyak 210 responden (52,5\%), mayoritas berusia 21-24 tahun sebanyak 144 responden (36\%), mayoritas berpendidikan terakhir SMA/SMK sebanyak 164 responden (41\%), mayoritas pekerjaan adalah pelajar/mahasiswa sebanyak 146 responden (36.,5\%), mayoritas berdomisili di Bandung Selatan sebanyak 112 responden (28\%), berpenghasilan Rp1.000.000 - Rp 3.000.000 sebanyak 153 responden $(38,25 \%)$, serta melakukan transaksi menggunakan TCASH sebesar Rp 25.000 - Rp 50.000/bulan sebanyak 128 responden (32\%). 


\section{Model Pengukuran (Outer Model)}

\section{Validitas Convergent}

Berdasarkan hasil pengujian loading factor menujukkan bahawa seluruh item kuesioner pada penelitian ini memiliki nilai loading factor lebih besar dari 0.7 dan dinyatakan valid. Menurut (Ghozali \& Latan, 2014) nilai loading factor yang dinyatakan valid harus lebih besar dari $0.7(>0.7)$.

Berdasarkan hasil pengujian AVE seluruh variabel dalam penelitian memiliki nilai Average Variance Extracted (AVE) lebih besar dari 0.5 dan dinyatakan valid. Menurut (Hair et al, 2017) "the AVE shoud be higher than 0.5". Begitu pula menurut (Ghozali \& Latan, 2014) bahwa nilai AVE harus lebih besar dari 0.5.

\section{Validitas Discriminant}

Berdasarkan hasil pengujian cross loading, seluruh nilai loading lebih besar dibandingkan dengan nilai cross loading nya, serta memiliki nilai lebih dari 0.7 dan dinyatakan valid. Menurut Hair, et. al (2017) "an indicator's outer loadings on a construct should be higher than its cross-loading with other construct". Begitu pula menurut (Ghozali \& Latan, 2014) nilai cross loading yang valid adalah lebih besar dari 0.7. Selanjutnya berdasarkan pengujian Fornell-Larcker criterion menunjukkan bahwa nilai akar kuadrat AVE pada setiap variabel lebih tinggi dibandingkan dengan nilai korelasi maka dapat disimpulkan bahwa model valid. Menurut (Ghozali \& Latan, 2014) untuk memenuhi discriminant validity nilai akar kuadrat AVE lebih tinggi daripada nilai korelasi antar konstruk.

\section{Reliabilitas}

Berdasarkan hasil pengujian reliabilitas, selutuh variabel dalam penelitian ini memiliki nilai cronbach's alpha dan composite reliability lebih besar dari 0.7 dan dinyatakan reliabel. Menurut (Ghozali \& Latan, 2014) nilai cronbach's alpha dan composite reliability harus lebih besar dari 0.7 .

\section{Model Struktural (Inner Model)}

\section{R Square}

Tabel 1. Hasil $R$ Square Model 1

\begin{tabular}{|l|c|}
\hline \multicolumn{1}{|c|}{ Variabel } & R Square \\
\hline Trust & 0.780 \\
\hline Satisfaction & 0.479 \\
\hline Loyalty & 0.851 \\
\hline Brand Equity & 0.471 \\
\hline
\end{tabular}

Sumber: (Hair, et. al, 2017)

Menurut (Hair, et. al, 2017) nilai $R$-Square 0.75, 0.50, 0.25 menunjukkan model kuat, moderate dan lemah. Berdasarkan hasil pengujian $R$-Square, menunjukkan variabel trust dengan nilai $R$-Square 0,780 dan loyalty dengan nilai $R$-Square 0,851 memiliki model yang kuat karena nilai $R$-Square nya lebih besar dari 0.75 . Variabel Trust dipengaruhi oleh Delivery

ISSN: 1829-8680 E-ISSN: 2599-0039 
Quality sebesar $78 \%$ sedangkan sisanya sebesar 22\% dipengaruhi variabel di luar penelitian ini. Selain itu, variabel Loyalty dipengaruhi oleh Trust dan Satisfaction sebesar 85,1\% sedangkan sisanya sebesar $14,9 \%$ dipengaruhi variabel diluar penelitian ini.

Variabel Satisfaction dengan nilai $R$-Square sebesar 0.479 dan variabel Brand Equity dengan nilai $R$-Square sebesar 0.471 memiliki model yang lemah karena nilai $R$-Square nya diantara 0.50 dan 0.25. Variabel Satisfaction dipengaruhi oleh variabel Outcome Quality sebesar $47.9 \%$ dan sisanya sebesar $52.1 \%$ dipengaruhi variabel diluar penelitian ini. Sedangkan variabel Brand Equity dipengaruhi oleh Loyalty sebesar $47.1 \%$ dan sisanya sebesar $52.9 \%$ dipengaruhi variabel diluar penelitian ini.

Tabel 2. Hasil R Square model 2

\begin{tabular}{|c|c|}
\hline Variabel & R Square \\
\hline Trust & 0.641 \\
\hline Satisfaction & 0.832 \\
\hline
\end{tabular}

Sumber: Data diolah peneliti

Variabel Trust dengan nilai $R$ Square sebesar 0.641 memiliki model moderate. Hal tersebut dikarenakan nilai $R$ Square nya berada diantara 0.5 dan 0.75 . Variabel Trust dipengaruhi oleh Loyalty sebesar 64,1\% dan sisanya sebesar 35,9\% dipengaruhi oleh variabel diluar penelitian ini.

Variabel Satisfaction dengan nilai $R$ Square sebesar 0.832 memiliki model kuat. Hal tersebut dikarenakan nilai $R$ Square lebih besar dari 0.75. Variabel Satisfaction dipengaruhi oleh Loyalty sebesar $83,2 \%$ dan sisanya sebesar $16,8 \%$ dipengaruhi oleh variabel diluar penelitian ini.

\section{Pengujian Hipotesis}

Tabel 3. Hasil Pengujian T Statistics

\begin{tabular}{|l|l|l|l|l|}
\hline Hipotesis & Jalur hubungan & T Statistics & $\boldsymbol{P}$ Values & Keterangan \\
\hline H1 & $\begin{array}{l}\text { Delivery Quality } \\
\rightarrow \text { Trust }\end{array}$ & 82,240 & 0,000 & H1 diterima \\
\hline H2 & $\begin{array}{l}\text { Outcome Quality } \\
\rightarrow \text { Satisfaction }\end{array}$ & 21,566 & 0,000 & H2 diterima \\
\hline H3 & Trust $\rightarrow$ Loyalty & 5,161 & 0,000 & H3 diterima \\
\hline H4 & $\begin{array}{l}\text { Satisfaction } \rightarrow \\
\text { Loyalty }\end{array}$ & 18,889 & 0,000 & H4 diterima \\
\hline H5 & $\begin{array}{l}\text { Loyalty } \rightarrow \\
\text { Brand Equity }\end{array}$ & 15,375 & 0,000 & H5 diterima \\
\hline H6 & Loyalty $\rightarrow$ Trust & 33,964 & 0,000 & H6 diterima \\
\hline H7 & $\begin{array}{l}\text { Loyalty } \rightarrow \\
\text { Satisfaction }\end{array}$ & 71,687 & 0,000 & H7 diterima \\
\hline
\end{tabular}

Sumber: Data diolah peneliti

Berdasarkan hasil pengujian hipotesis pada Tabel 3. menunjukkan seluruh hipotesis diterima. Menurut (Ghozali \& Latan, 2014) untuk pengujian hipotesis dengan tingkat signifikansi 5\% yang diterima memiliki nilai lebih besar dari 1.65. (Ghozali \& Latan, 2014). Sedangkan menurut (Hair, et. al, 2017) nilai rule of thumb T statistics pada tingkat signifikansi 
5\% adalah 1.65. Untuk $p$ values, menurut (Hair, et. al, 2017) untuk tingkat signifikansi 5\% nilai $p$ values harus lebih kecil dari 0.05 .

\section{Pembahasan}

\section{H1: Delivery quality memiliki pengaruh positif dan signifikan terhadap Trust}

Berdasarkan hasil penelitian, terdapat pengaruh variabel Delivery Quality terhadap Customer Trust dengan nilai $T$ statistics sebesar 82,240 (>1,64). Hal tersebut menyatakan bahwa hubungan antara variabel Delivery Quality terhadap Trust memiliki pengaruh positif dan signifikan yang berarti $\mathrm{H} 1$ diterima. Selanjutnya berdasarkan hasil pengujian $R$ Square, menunjukkan nilai $R$ Square pada variabel Trust yang dipengaruhi oleh Delivery Quality senilai 0.780 yang menunjukkan model kuat. Maka dapat disimpulkan bahwa Delivery quality yang dirasakan oleh konsumen layanan Tcash di Kota Bandung dapat mempengaruhi tingkat kepercayaan konsumen pada layanan Tcash di Kota Bandung.

Hasil penelitian ini memiliki kesamaan dengan penelitian terdahulu yang dilakukan oleh (Kao \& Lin, 2016) bahwa Delivery Quality memiliki pengaruh positif dan signifikan terhadap Trust. Berdasarkan kesamaan tersebut maka dapat dikonfirmasi bahwa terdapat kesamaan hasil penelitian meskipun berbeda lokasi penelitian. Berdasarkan kesamaan tersebut maka dapat dikonfirmasi bahwa terdapat kesamaan hasil penelitian meskipun berbeda lokasi penelitian. Hal tersebut juga membuktikan bahwa Delivery Quality pada layanan mobile banking dapat mempengaruhi tingkat kepercayaan konsumen terhadap layanan mobile banking.

\section{H2 : Outcome quality memiliki pengaruh positif dan signifikan terhadap Satisfaction}

Berdasarkan hasil penelitian, terdapat pengaruh variabel Outcome Quality terhadap Customer Satisfaction memiliki nilai $T$ statistics sebesar 21,566 (>1,64). Hal tersebut menunjukkan Outcome Quality mempunyai pengaruh positif dan signifikan terhadap variabel Customer Satisfaction yang berarti $\mathrm{H} 2$ diterima. Selanjutnya berdasarkan hasil pengujian $R$ Square, menunjukkan nilai $R$ Square pada variabel Satisfaction yang dipengaruhi oleh Outcome Quality senilai 0.479 yang menunjukkan model moderate. Maka dapat disimpulkan bahwa Outcome Quality yang dirasakan oleh konsumen layanan Tcash di Kota Bandung dapat mempengaruhi tingkat kepuasan konsumen pada layanan Tcash di Kota Bandung.

Hasil penelitian ini memiliki kesamaan dengan penelitian terdahulu yang dilakukan oleh (Kao \& Lin, 2016) bahwa Outcome Quality memiliki pengaruh positif dan signifikan terhadap Satisfaction. Berdasarkan kesamaan tersebut maka dapat dikonfirmasi bahwa terdapat kesamaan hasil penelitian meskipun berbeda lokasi penelitian. Hal tersebut juga membuktikan bahwa Outcome Quality pada layanan mobile banking dapat mempengaruhi tingkat kepuasan konsumen terhadap layanan mobile banking.

\section{H3 : Trust memiliki pengaruh positif dan signifikan terhadap Loyalty}

Berdasarkan hasil penelitian, terdapat pengaruh variabel Trust terhadap variabel Loyalty memiliki nilai T statistics sebesar 5,161 $(<1,64)$. Hal tersebut menunjukkan Trust memiliki pengaruh positif dan signifikan terhadap Loyalty. Yang berarti H3 diterima. Selanjutnya berdasarkan hasil pengujian $\mathrm{R}$, menunjukkan nilai $R$ Square pada variabel Loyalty yang dipengaruhi oleh Trust dan Satisfaction senilai 0.851 yang menunjukkan model kuat. Maka 
dapat disimpulkan bahwa kepercayaan konsumen layanan Tcash di Kota Bandung dapat mempengaruhi tingkat loyalitas konsumen pada layanan Tcash di Kota Bandung.

Hasil penelitian ini memiliki kesamaan dengan penelitian terdahulu yang dilakukan oleh (Kao \& Lin, 2016) bahwa Trust memiliki pengaruh positif dan signifikan terhadap Loyalty. Berdasarkan kesamaan tersebut maka dapat dikonfirmasi bahwa terdapat kesamaan hasil penelitian meskipun berbeda lokasi penelitian. Hal tersebut juga membuktikan bahwa kepercayaan konsumen pada layanan mobile banking dapat mempengaruhi tingkat loyalitas konsumen terhadap layanan mobile banking.

\section{H4: Satisfaction memiliki pengaruh positif dan signifikan terhadap Loyalty}

Berdasarkan hasil penelitian, terdapat pengaruh variabel Customer Satisfaction terhadap Loyalty memiliki nilai $T$ statistics sebesar 18,889 (>1,64). Hal tersebut menunjukkan Satisfaction mempunyai pengaruh positif dan signifikan terhadap variabel Loyalty yang berarti $\mathrm{H} 4$ diterima. Selanjutnya berdasarkan hasil pengujian $R$ Square pada, menunjukkan nilai $R$ Square pada variabel Loyalty yang dipengaruhi oleh Trust dan Satisfaction senilai 0.851 yang menunjukkan model kuat. Maka dapat disimpulkan bahwa kepuasan konsumen layanan Tcash di Kota Bandung dapat mempengaruhi tingkat loyalitas konsumen pada layanan Tcash di Kota Bandung.

Hasil penelitian ini memiliki kesamaan dengan penelitian terdahulu yang dilakukan oleh (Kao \& Lin, 2016) bahwa Satisfaction memiliki pengaruh positif dan signifikan terhadap Loyalty. Berdasarkan kesamaan tersebut maka dapat dikonfirmasi bahwa terdapat kesamaan hasil penelitian meskipun berbeda lokasi penelitian. Hal tersebut juga membuktikan bahwa kepuasan konsumen pada layanan mobile banking dapat mempengaruhi tingkat loyalitas konsumen pada layanan mobile banking.

\section{H5: Loyalty memiliki pengaruh positif yang signifikan terhadap Brand equity}

Berdasarkan hasil penelitian, terdapat pengaruh variabel Loyalty terhadap Brand Equity memiliki nilai $T$ statistics sebesar $15,375(>1,64)$. Hal tersebut menunjukkan Loyalty mempunyai pengaruh positif dan signifikan terhadap variabel Brand Equity yang berarti H5 diterima. Selanjutnya berdasarkan hasil pengujian $R$ Square, menunjukkan nilai $R$ Square pada variabel Brand Equity yang dipengaruhi oleh Loyalty senilai 0.471 yang menunjukkan model moderate. Maka dapat disimpulkan bahwa loyalitas konsumen layanan Tcash di Kota Bandung dapat mempengaruhi tingkat ekuitas merek konsumen pada layanan Tcash di Kota Bandung.

Hasil penelitian ini memiliki kesamaan dengan penelitian terdahulu yang dilakukan oleh (Kao \& Lin, 2016) bahwa Delivery Quality memiliki pengaruh positif dan signifikan terhadap Trust. Berdasarkan kesamaan tersebut maka dapat dikonfirmasi bahwa terdapat kesamaan hasil penelitian meskipun berbeda lokasi penelitian. Hal tersebut juga membuktikan bahwa loyalitas konsumen pada layanan mobile banking dapat mempengaruhi tingkat ekuitas merek penyedia layanan mobile banking.

\section{H6: Loyalty memiliki pengaruh positif dan signifikan terhadap Trust}

Berdasarkan hasil penelitian, terdapat pengaruh variabel Trust terhadap variabel Loyalty memiliki nilai T sebesar 33,964 (>1,64). Hal tersebut menunjukkan Trust memiliki pengaruh positif dan signifikan terhadap Loyalty. Yang berarti H6 diterima. Selanjutnya berdasarkan hasil

ISSN: 1829-8680 E-ISSN: 2599-0039 
pengujian $R$ Square, menunjukkan nilai $R$ Square pada variabel Trust yang dipengaruhi oleh Trust dan Satisfaction senilai 0.641 yang menunjukkan model kuat. Maka dapat disimpulkan bahwa loyalitas konsumen layanan Tcash di Kota Bandung dapat mempengaruhi tingkat kepercayaan konsumen pada layanan Tcash di Kota Bandung.

Hasil penelitian ini memiliki kesamaan dengan penelitian terdahulu yang dilakukan oleh (Kao \& Lin. 2016) bahwa Loyalty memiliki pengaruh positif dan signifikan terhadap Trust. Berdasarkan kesamaan tersebut maka dapat dikonfirmasi bahwa terdapat kesamaan hasil penelitian meskipun berbeda lokasi penelitian. Hal tersebut juga membuktikan bahwa loyalitas konsumen pada layanan mobile banking dapat mempengaruhi tingkat kepercayaan penyedia layanan mobile banking.

\section{H7 : Loyalty memiliki pengaruh positif dan signifikan terhadap Satisfaction}

Berdasarkan hasil penelitian, terdapat pengaruh variabel Loyalty terhadap variabel Satisfaction memiliki nilai $T$ statistics sebesar $71,687(>1,64)$. Hal tersebut menunjukkan Loyalty memiliki pengaruh positif dan signifikan terhadap Satisfaction. Yang berarti $\mathrm{H}$ diterima. Selanjutnya berdasarkan hasil pengujian $R$ Square, menunjukkan nilai $\mathrm{R}$ Square pada variabel Trust yang dipengaruhi oleh Trust dan Satisfaction senilai 0.832 yang menunjukkan model kuat. Maka dapat disimpulkan bahwa loyalitas konsumen layanan Tcash di Kota Bandung dapat mempengaruhi tingkat kepuasan konsumen pada layanan Tcash di Kota Bandung.

Hasil penelitian ini memiliki kesamaan dengan penelitian terdahulu yang dilakukan oleh (Kao \& Lin, 2016) bahwa Loyalty memiliki pengaruh positif dan signifikan terhadap Satisfaction. Berdasarkan kesamaan tersebut maka dapat dikonfirmasi bahwa terdapat kesamaan hasil penelitian meskipun berbeda lokasi penelitian. Hal tersebut juga membuktikan bahwa loyalitas konsumen pada layanan mobile banking dapat mempengaruhi tingkat kepuasan konsumen layanan mobile banking.

\section{KESIMPULAN DAN SARAN}

\section{Kesimpulan}

Kesimpulan pada penelitian ini adalah: (1) Variabel Delivery Quality memiliki pengaruh positif dan signifikan terhadap Trust dengan besar hubungan sebesar 0.833. Maka Delivery Quality yang dirasakan oleh konsumen dapat mempengaruhi tingkat kepercayaan pada konsumen layanan Tcash di Kota Bandung. (2) Variabel Outcome Quality memiliki pengaruh positif dan signifikan terhadap Satisfaction dengan besar hubungan sebesar 0.692. Maka Outcome Quality yang dirasakan oleh konsumen dapat mempengaruhi tingkat kepuasan pada konsumen layanan Tcash di Kota Bandung. (3) Variabel Trust memiliki pengaruh positif dan signifikan terhadap Loyalty dengan besar hubungan sebesar 0.218. Maka tingkat kepercayaan konsumen dapat mempengaruhi tingkat loyalitas konsumen layanan Tcash di Kota Bandung. (4) Variabel Satisfaction memiliki pengaruh positif dan signifikan terhadap Loyalty dengan besar hubungan sebesar 0.742 . Maka tingkat kepuasan konsumen dapat mempengaruhi tingkat loyalitas konsumen layanan Tcash di Kota Bandung. (5) Variabel Loyalty memiliki pengaruh positif dan signifikan terhadap Brand Equity dengan besar hubungan sebesar 0.686. Maka tingkat loyalitas konsumen dapat mempengaruhi tingkat ekuitas merek Tcash di Kota Bandung. (6) Variabel Loyalty memiliki pengaruh positif dan signifikan terhadap Trust dengan besar hubungan sebesar 0.801. Maka tingkat loyalitas konsumen dapat mempengaruhi tingkat 
kepercayaan konsumen layanan Tcash di Kota Bandung. (7) Variabel Loyalty memiliki pengaruh positif dan signifikan terhadap Satisfaction dengan besar hubungan sebesar 0.912. Maka tingkat loyalitas konsumen dapat mempengaruhi tingkat kepuasan konsumen layanan Tcash di Kota Bandung.

\section{Saran}

\section{Saran Bagi PT Telkomsel}

Berdasarkan hasil penelitian ini, terdapat beberapa hal yang dapat dijadikan saran bagi penyedia layanan Tcash yaitu PT Telkomsel. Melihat fenomena bahwa kecilnya tingkat loyalitas pada pengguna Tcash, maka saran yang penulis ajukan adalah sebagai berikut: (1) PT Telkomsel selaku penyedia layanan Tcash sebaiknya meningkatkan tingkat kepercayaan konsumen dengan cara menunjukkan kepedulian dengan konsumen, seperti menyediakan layanan keluhan yang mampu merespon keluhan maupun feedback dari konsumen mengenai layanan Tcash pada aplikasi Twallet. (2) PT Telkomsel selaku penyedia layanan Tcash sebaiknya meningkatkan tingkat kepuasan konsumen dengan cara melakukan interaksi interaktif seperti menciptakan program feedback kepuasan pelanggan, hasil dari program feedback kepuasan tersebut dijadikan acuan dalam melakukan improvement pada kualitas layanan maupun layanan baru yang akan ditawarkan oleh Tcash di masa yang akan datang.

\section{Saran Bagi Peneliti Selanjutnya}

Penelitian ini memiliki beberapa keterbatasan, maka peneliti memberikan saran yang dapat dijadikan bahan pertimbangan bagi peneliti selanjutnya, yaitu sebagai berikut: (1) Objek yang dianalisis pada penelitian ini adalah salah satu jenis alat transaksi non-tunai (E-Money) yaitu Mobile Wallet. Maka dari itu, pada penelitian selanjutnya objek yang dapat dianalisis alat transaksi mobile banking lain. (2) Menambahkan variabel age, gender dan usage time untuk memperkuat model hubungan terhadap satisfaction dan loyalty. (3) Menambahkan variabel religious, political, and economic values untuk memperkuat model hubungan terhadap trust.

\section{DAFTAR PUSTAKA}

Abdillah, Willy dan Jogiyanto (2015). Partial Least Square (PLS) Alternatif Strukural Equation Modeling (SEM) dalam penelitian bisnis. Yogyakarta: Andi

Bank Indonesia, www.bi.go.id [23 Oktober 2017]

Ghozali, Imam dan Hengky Latan . (2014). Partial Least Squares Konsep, Teknik dan Aplikasi Menggunakan Program SmartPLS 3.0. Semarang: Badan Penerbit Universitas Diponegoro.

Hair, J. F., Hult, G. T., Ringle, C. M., \& Sarstedt, M. (2017). A Primer on Partial Least Squares Structural Equation Modeling (PLS-SEM) Second Edition. California: SAGE Publications, Inc. 
Kao, Ta-Wei dan Winson T Lin, (2016). The relationship between perceived e-service quality and brand equity: A simultaneous equations system approach. Computers in Human Behavior, 57 208-218. Retreived from Elsevier

Kotler, Philip dan Kevin Lane Keller. (2016). Marketing Management. Global Edition Pearson Prentice Hall.

Lukihardianti, Arie dan Elba Damhuri (2017,23 Oktober) Pengguna Tcash Telkomsel Melonjak [online]. Tersedia: www.republika.co.id [23 Oktober 2017]

Tcash, https://digitalpayment.telkomsel.com Diakses pada tanggal 1 November 2017 